TELAGA BAHASA

$\begin{array}{ll}\text { Volume } 5 & \text { No. } 1 \text { Juni } 2017\end{array}$

Halaman 127-142

\title{
TINJAUAN PSIKOLOGI SASTRA TERHADAP TOKOH UTAMA NOVEL REMBULAN TENGGELAM DI WAJAHMU KARYA TERE LIYE
}

\section{(Psychological Aproach to The Main Character in Tere Liye's Work Rembulan Tenggelam di Wajahmu)}

\author{
Ratih Rahayu
}

Kantor Bahasa Provinsi Lampung

Jalan Beringin II no. 40 Kompleks Gubernuran Telukbetung, Bandarlampung Telepon (0721) 486408, (0721) 480705, Faksimile (0721) 486407

Pos-el: ahza.yayaya@gmail.com

\begin{abstract}
Abstrak
Tulisan ini mendeskripsikan tokoh utama novel Rembulan Tenggelam Di Wajahmu (RTDW) karya Tere Liye ditinjau dari psikologi sastra khususnya teori psikoanalisis Sigmund Freud. Tokoh utama dalam novel ini adalah Ray atau Rehan Rejana. Kisah dalam RTDW didominasi oleh pergolakan batin tokoh utamanya. Tokoh utama novel ini dikisahkan diberi kesempatan untuk melakukan perjalanan mengenai masa lalunya demi menjawab lima pertanyaan dalam hidupnya itu. Pada bagian awal, id Ray muncul secara dominan dan terlihat tidak mampu diimbangi oleh ego dan superego-nya. Ada beberapa saat di mana id Ray muncul dan menjadi dominan. Ada saat di mana Ray juga tidak dapat menerima kenyataan dan merasa Tuhan tidak bersikap adil padanya serta suka merenggut kebahagiaan dari orang-orang baik. Di balik semua bentuk protesnya pada Tuhan, superego tokoh utama RTDW ini masih muncul terutama saat melihat rembulan. Dikisahkan bahwa Ray diberi kesempatan lima hari sebelum kematiannya untuk mengendalikan dominasi id-nya sehingga akhirnya id, ego, dan superegonya berjalan beriringan.
\end{abstract}

Kata kunci: psikologi sastra, tokoh utama, novel, RTDW

\footnotetext{
Abstract

This paper described the main character of the novel Rembulan Tenggelam Di Wajahmu (The Moon Drowning In Your Face/RTDW) Tere Liye works of literature, especially in terms of the psychology of Sigmund Freud's theory of psychoanalysis. The main character in this novel is Ray or Rehan Rejana. Stories in RTDW inner turmoil dominated by the main character. The main character of this novel narrated given the opportunity to travel about his
} 
past in order to answer five questions in his life. At the beginning, Ray's id appears dominant and looks incapable of being offset by his ego and superego. There are times when Ray's id appears and becomes dominant. There are times when Ray can not accept reality and feel God is not being fair to him and likes to snatch the happiness of good people. Behind all forms of protest to God, the main character superego of RTDW is still present especially when looking at the moon. It is said that Ray was given a chance five days before his death to control the dominance of his id so that finally id, ego, and superego him go hand in hand.

Keywords: psychology literature, the main character, novel, RTDW

\section{PENDAHULUAN}

Kehidupan Tere Liye yang bernama asli Darwis lahir di Lahat, 21 Mei 1979 dikenal sebagai penulis novel yang cukup produktif. Beberapa novel karyanya bahkan pernah diangkat ke layar kaca, yaitu Hafalan Shalat Delisa dan Moga Bunda Disayang Allah. Tere Liye meyelesaikan pendidikan dasar dan menengahnya di SDN 2 Kikim Timur dan SMPN 2 Kikim, Kabupaten Lahat, Provinsi Sumatra Selatan. Setelah lulus SMP, ia melanjutkan sekolahnya ke SMAN 9 Bandarlampung, Provinsi Lampung. Setamat SMA di Lampung, ia melanjutkan studinya ke Fakultas Ekonomi Universitas Indonesia.

Meskipun bukan berlatar belakang jurusan bahasa dan sastra, Tere Liye cukup meraih keberhasilan di dunia literasi Indonesia. Bahkan yang mengejutkan adalah ternyata kegiatan menulis cerita awalnya hanya sekadar menjadi hobinya. Pada awalnya, setelah selesai mengikuti perkuliahan ia banyak mengisi waktunya dengan menulis buku-buku fiksi. Setelah menyelesaikan kuliahnya dan menjadi seorang akuntan, ia tetap melanjutkan hobi menulisnya hingga pada akhirnya serius mendalami dunia tulis menulis. Karyakaryanya antara lain Bumi (2014), Bulan (2015), Matahari (201), Bintang (2017), Hujan (201), Pulang (2015), Pukat (2010), Burlian (2009), Eliana (2011), Amelia (2013), Negeri di Ujung Tanduk (2013), Negeri Para Bedebah (2012), Hafalan Shalat Delisa (2005).

Saat ini Tere Liye termasuk novelis Indonesia yang sedang naik daun karena karya-karya cukup laris di pasaran dan karya barunya selalu ditunggu penggemarnya. Pandangan tokoh-tokoh yang dikisahkan dalam karya-karyanya sarat tentang nilainilai kehidupan, pertentangan batin dalam menentukan pilihan, menentukan keputusan tentang baik dan buruk, kekecewaan dan penyesalan, serta masalah kehidupan seharihari yang memberikan banyak pelajaran bagi pembacanya. Begitu pula dalam karyanya 
yang berjudul Rembulan Tenggelam $D i$ Wajahmu.

Novel Rembulan Tenggelam Di Wajahmu karya Tere Liye merupakan salah satu karya novel yang laris manis di pasaran. Hal tersebut terbukti dalam dua tahun, novel ini telah lima kali cetak ulang. Buku ini diterbitkan oleh Republika, cetakan ke-1 terbit pada Februari 2009, cetakan ke-2 April 2009, cetakan ke-3 Agustus 2009, cetakan ke-4 Februari 2010, cetakan ke-5 November 2010, dan cetakan ke-6 Maret 2011. Untuk selanjutnya, Rembulan Tenggelam Di Wajahmu akan disingkat menjadi RTDW.

Novel RTDW terdiri dari 37 bab yang terpapar dalam 425 halaman. Salah satu keunikan dalam novel ini adalah di setiap judul bab diawali dengan kata "Aku”. Pada bab 1 diberi judul "Aku Rinai”, bab 2 "Aku Rehan", bab 3 "Aku Pasien", bab 4 "Aku Diar", bab 5 "Aku Terminal Kota", dan seterusnya.

Kisah dalam RTDW didominasi oleh pergolakan batin tokoh utamanya, yaitu Ray akan lima pertanyaan yang selalu muncul dalam hatinya. Ray, tokoh utama dalam novel ini dikisahkan diberi kesempatan untuk melakukan perjalanan mengenai masa lalunya demi menjawab lima pertanyaan dalam hidupnya itu.

Dalam tulisan singkat di belakang bukunya, Tere Liye mengajak pembaca untuk menutup mata dan pikiran kita dari carut marut kehidupan. Pembaca disarankan untuk membayangkan bahwa saat ini ada satu malaikat bersayap indah yang datang kepada kita, lantas lembut berkata: " $A k u$ memberikan kesempatan hebat. Lima kesempatan untuk bertanya tentang rahasia kehidupan, dan aku akan menjawabnya langsung sekarang. Lima pertanyaan. Lima jawaban. Apakah pertanyaan pertamamu?". Pembaca diajak untuk berpikir mengenai hidup dan kehidupan yang dijalaninya. Tere Liye juga memberikan pengantar bahwa tentang perjalanan hidup itu hanya ada satu rumus, yaitu semua urusan adalah sederhana.

Banyak komentar positif yang muncul dari pembaca novel RTDW ini. Ida Safitri mengungkapkan bahwa RTDW ini adalah "novel yang keras dan menyentuh tentang anak manusia yang apa adanya”. Sita Elanda Lestari, seorang mahasiswa Universitas Indonesia mengungkapkan bahwa "novel RTDW ini mengajarkan saya bagaimana memaknai kehilangan. Rasa kehilangan yang begitu rumit, sakit, tapi tidak untuk Tere Liye, semuanya begitu indah dalam bingkai kesederhanaan". Selain itu Ratih Sang, seorang model yang saat ini menjadi anggota DPR berkomentar bahwa "ketika Anda membaca novel Tere Liye kali ini, terasa sekali betapa tidak dapatnya kita berandai-andai." 
Berangkat dari keunikan yang ditemukan dalam novel RTDW ini, saya tertarik untuk mengkaji lebih jauh aspek kepribadian tokoh utama. Pemaparan yang menarik tentang perjalanan hidup manusia yang diputar ulang agar tokoh utama dapat mengerti makna hidup dan kehidupannya layak untuk dikaji. Pengkajian kepribadian tokoh utama akan ditinjau dari ilmu psikologi sastra umumnya dan tinjauan psikoanalisis pada khususnya dengan mengangkat permasalahan" bagaimanakan tokoh utama dalam Novel Rembulan yang Tenggelam di Wajahmu dalam tinjauan psikologi sastra?

Kajian ini diharapkan mampu menghasilkan tulisan yang bermanfaat untuk menambah pengetahuan mengenai studi analisis sastra Indonesia, terutama dalam bidang penelitian novel yang memanfaatkan teori psikologi sastra. Hasil kajian ini juga diharapkan dapat menambah referensi penelitian karya sastra Indonesia dan menambah wawasan kepada pembaca tentang bentuk kepribadian. Selain itu, melalui pemahaman mengenai perkembangan kepribadian tokoh utamanya, diharapkan dapat membantu pembaca dalam mengungkapkan pesan yang terkandung dalam novel RTDW.

\section{PSIKOLOGI SASTRA}

Psikologi dalam Kamus Besar Bahasa Indonesia (KBBI) berarti ilmu yang berkaitan dengan proses mental, baik normal maupun abnormal dan pengaruhnya pada perilaku atau ilmu pengetahuan tentang gejala dan kegiatan jiwa. Plato dan Aristoteles berpendapat bahwa psikologi adalah ilmu pengetahuan yang mempelajari tentang hakikat jiwa serta prosesnya sampai akhir. Sejalan dengan itu, Abu Ahmadi (1992:5) mengungkapkan bahwa psikologi merupakan ilmu pengetahuan yang mempelajari semua tingkah laku dan perbuatan individu, di mana individu tersebut tidak dapat dilepaskan dari lingkungannya.

Sastra adalah suatu kegiatan kreatif yang berbentuk karya seni yang menggunakan bahasa sebagai mediumnya. Karya sastra biasanya menampilkan gambaran kehidupan yang sesungguhnya merupakan gambaran kenyataan sosial akibat adanya proses kreatif pengarang dalam merekam kehidupan yang ada di sekitarnya. Singkatnya, karya sastra merupakan karya imajinatif yang diolah dan dipadukan dengan kenyataan sosial yang ada di sekitar pengarang.

Mengenai hubungan psikologi dengan sastra menurut Bertens (2006: 60) mengungkapkan bahwa keduanya terdapat hubungan yang cukup erat, keduanya sama- 
sama berobjekkan manusia. Psikologi ke dalam teks dan dilengkapi dengan mempelajari tingkah laku dan jiwa manusia, kejiwaannya.

sedangkan sastra berbicara tentang

Menurut Wellek dan Werren (1995:

kehidupan manusia. Karena memiliki 108), hubungan antara psikologi dengan

kesamaan objek, maka keduanya sastra adalah bahwa di satu pihak karya memungkinkan untuk saling membantu. sastra dianggap sebagai hasil aktivitas dan Kaitan psikologi dan sastra adalah bahwa ekspresi manusia. Di pihak lain, psikologi psikologi merupakan ilmu bantu yang sangat relevan, karena dari proses pemahaman karya sastra dapat ditimba mengenai ajaran dan kaidah psikologi.

Menurut Atar Semi, psikologi sastra adalah suatu disiplin ilmu yang mengkaji kandungan suatu karya sastra yang memuat peristiwa kehidupan manusia yang diperankan oleh tokoh-tokoh yang imajiner yang ada di dalam atau mungkin diperankan oleh tokoh-tokoh faktual. Hal ini, merangsang pembaca untuk mengetahui lebih jauh tentang seluk beluk manusia yang beraneka ragam. Psikologi sastra menurut Endraswara (2003: 96) adalah kajian sastra yang memandang karya sastra sebagai aktivitas kejiwaan. Pengarang akan menggunakan cipta, rasa dan karsa dalam berkarya. Begitu pula pembaca, dalam menanggapi karya juga tidak lepas dari kejiwaan masing-masing. Bahkan sebagaimana sosiologi refleksi, psikologi sastra pun mengenal karya sastra sebagai pantulan kejiwaan. Pengarang akan sendiri dapat membantu pengarang dalam mengenalkan kepekaan dan memberi kesempatan untuk menjajaki pola-pola yang belum pernah terjamah sebelumnya. Hasil yang bisa diperoleh adalah kebenaran yang mempunyai nilai-nilai artistik yang menambah koherensi dan kompleksitas karya sastra tersebut.

Perkembangan pemikiran dan kajian empirik di kalangan para ahli tentang kepribadian manusia telah melahirkan berbagai teori yang beragam sesuai dengan perspektif pemikiran dan pengalaman pribadi para ahli yang membangun teori tersebut. Teori-teori kepribadian yang dikenal dewasa ini oleh masyarakat di antaranya adalah teori psikoanalisis, behavioristik, dan humanistik.

Penggagas teori psikoanalisis adalah Sigmund Freud. Menurut Freud dalam Yusuf dan Nurihsan (2007: 35), ada dua asumsi yang mendasari teori psikoanalisis Freud, yaitu (1) asumsi determinisme psikis dan (2) asumsi motivasi tak sadar. Asumsi determinisme psikis (psychic determinism) menangkap gejala kejiwaan kemudian diolah meyakini bahwa segala sesuatu yang 
dilakukan, dipikirkan, atau dirasakan rasional dan orientasinya bersifat individu mempunyai arti dan maksud, dan itu fantasi/maya. semuanya secara alami sudah ditentukan. Menurut Freud (1984:XL) id Adapun asumsi motivasi tak sadar merupakan bahan dasar bagi pembentukan (unconscious motivation) meyakini bahwa hidup psikis lebih lanjut yang tidak sebagian besar tingkah laku individu (seperti terpengaruh oleh kontrol pihak ego dan perbuatan, berfikir, dan merasa) ditentukan prinsip realitas. Dalam id tidak dikenal oleh motif tak sadar. Freud membagi struktur kepribadian menjadi tiga komponen, yaitu: 1) id (Das Es), aspek biologis kepribadian; 2) ego (Das Ich), aspek psikologi kepribadian; 3) superego (Dash Uber Ich), aspek sosiologi kepribadian.

Perilaku seseorang merupakan hasil interaksi antara ketiga komponen di atas. Id merupakan komponen kepribadian yang primitif, instingtif (yang berusaha untuk memenuhi kepuasan insting) dan rahim tempat ego dan superego berkembang. Id berorientasi pada prinsip kesenangan (pleasure principle) atau prinsip reduksi ketegangan. Id merupakan sumber energi psikis. Maksudnya bahwa id itu merupakan sumber dari insting kehidupan (eros) atau dorongan-dorongan biologis (makan, minum, tidur, bersetubuh, dsb.) dan insting kematian/insting agresif (tanatos) yang menggerakkan tingkah laku. Prinsip kesenangan merujuk kepada pencapaian kepuasan yang segera dari dorongandorongan biologis tersebut. Id merupakan proses primer yang bersifat primitif, tidak urutan waktu dan hukum-hukum logika juga tidak berlaku baginya. Tetapi sudah ada struktur tertentu berkat pertentangan antara dua macam naluri, yaitu naluri kehidupan dan kematian.

Ego merupakan eksekutif atau manajer dari kepribadian yang membuat keputusan (decision maker) tentang instinginsting mana yang akan dipuaskan dan bagaimana caranya atau sebagai sistem kepribadian yang terorganisasi, rasional, dan berorientasi pada prinsip realitas. Peranan utama ego adalah sebagai mediator (perantara) atau yang menjembatani id (keinginan yang kuat untuk mencapai kepuasan yang segera) dengan kondisi lingkungan atau dunia luar yang diharapkan. Ego bertujuan untuk mencegah terjadinya ketegangan sampai ditemukan suatu obyek yang cocok untuk pemuasan kebutuhan atau dorongan $i d$. Seperti halnya $i d$, ego pun mempunyai keinginan untuk memaksimalkan pencapaian kepuasan, hanya dalam prosesnya, ego berdasarkan kepada "secondary process thinking". Proses 
sekunder adalah berfikir realistik yang bersifat rasional, realistik, dan berorientasi pada pemecahan masalah. Dalam proses sekunder ini termasuk pula fungsi-fungsi persepsi, belajar, memori. Ego merumuskan suatu rencana untuk memuaskan kebutuhan atau dorongan dan kemudian menguji rencana itu.

Menurut Freud dalam Yusuf dan Nurihsan (2007: 36-37), hal yang harus diperhatikan dalam ego adalah (1) ego merupakan bagian dari id yang bertugas untuk memuaskan kebutuhan $i d$, bukan untuk mengecewakannya, (2) seluruh energi (daya) berasal dari id, (3) peran utamanya menengahi kebutuhan id dan kebutuhan lingkungan sekitar, dan 4) ego bertujuan untuk mempertahankan kebutuhan individu dan pengembangbiakannya. Superego merupakan komponen moral kepribadian yang terkait dengan standar atau norma masyarakat mengenai baik dan buruk, benar dan salah. Melalui pengalaman hidup, terutama pada usia anak, individu telah menerima latihan atau informasi tentang tingkah laku yang baik dan yang buruk. Individu menginternalisasi berbagai norma sosial atau prinsip-prinsip moral tertentu, kemudian menuntut individu yang bersangkutan untuk hidup sesuai dengan norma tersebut. Superego berfungsi untuk (1) merintangi dorongan-dorongan $i d$, terutama dorongan seksual dan agresif, karena dalam perwujudannya sangat dikutuk oleh masyarakat, (2) mendorong ego untuk menggantikan tujuan-tujuan realistik dengan tujuan-tujuan moralistik, dan (3) mengejar kesempurnaan (perfection).

Kajian-kajian sebelumnya mengenai novel RTDW ini pernah dilakukan oleh Anita Anggraini yang menganalisis dari sisi sosiologisnya. Namun sesungguhnya kajian Anita lebih menjurus pada analisis unsur intrinsiknya. Selain itu, analisis unsur intrinsiknya secara khusus juga telah dilakukan oleh Silvi Ananti Nabilah (2013). Kus Kusmiati (2013) juga pernah menganalisis novel RTDW dikaitkan dengan pembelajaran di sekolah, dan diberi judul Kajian Unsur Bawah Sadar Tokoh Utama Novel RTDW Karya Tere Liye dengan Psikoanalisis dan Relevansinya sebagai Bahan Ajar di Kelas XI SMA. Kajian lain yang menggunakan kajian psilogi sastra pernah dilakukan Sangidu terhadap Cerpen Nawal El Sadawi yang berjudul Kondisi Kejiwaan Para Tokoh dalam Kanat Hiyal Adh'af yang berfokus pada kondisi psikologis para tokoh dalam cerpen tersebut. Hasil penelitian itu menunjukkan bahwa para tokoh Mempelai Laki- Laki, Mempelai Perempuan, Ibu Mempelai Laki-Laki dan Ayah Mempelai Perempuan mengalami kecemasan dan ketidakstabilan 
jiwa dengan penyebab yang berbeda dalam menghadapi budaya tes keperawanan. Hanya tokoh Ibu Mempelai Laki- Laki yang tidak cemas karena jiwanya kuat

Dari berbagai penelitian atau kajian yang telah dilakukan sebelumnya, belum ada kajian yang secara khusus berfokus pada tokoh utamanya. Oleh karena itu, kajian ini secara khusus ingin mengupas lebih jauh tokoh utama novel RTDW ditinjau dari sisi psikologinya. Kapan dorongan id, ego dan superego-nya muncul, pada halaman berapa dan bagaimana kutipan kalimat atau paragrafnya.

Tinjauan Psikologi Sastra terhadap Tokoh Utama Novel RTDW

Menurut Roekhan dalam Endraswara (2003: 97-98), psikologi sastra ditopang oleh tiga pendekatan sekaligus. Pertama, pendekatan tekstual, yang mengkaji aspek psikologis tokoh dalam karya sastra. Kedua, pendekatan reseptif-pragmatik, yang mengkaji aspek psikologis pembaca sebagai penikmat karya sastra yang terbentuk dari pengaruh karya yang dibacanya, serta proses resepsi pembaca dalam menikmati karya sastra. Ketiga, pendekatan ekspresif yang mengkaji aspek psikologis sang penulis ketika melakukan proses kreatif yang terproyeksi lewat karyanya, baik penulis sebagi pribadi maupun wakil masyarakat.

Berkaitan dengan tokoh-tokoh cerita, dalam cerita fiksi dapat dibedakan ke dalam beberapa jenis penamaan berdasarkan dari sudut mana penamaan itu dilakukan. Berdasarkan perbedaan sudut pandang dan tinjauan, seorang tokoh dapat saja dikategorikan ke dalam beberapa jenis penamaan sekaligus, misalnya sebagai tokoh utama-prontagonis-berkembang-tipikal (Nurgiyantoro, 2007: 176).

Nurgiyantoro, (2007: 176-177) juga membagi kriteria tokoh menjadi beberapa bagian yaitu adanya tokoh utama dan tokoh tambahan, tokoh prontagonis dan antagonis, tokoh sederhana dan tokoh bulat, tokoh statis dan tokoh berkembang, dan tokoh tipikal dan tokoh netral. Tokoh utama adalah tokoh yang diutamakan penceritaannya dalam novel yang bersangkutan ia merupakan tokoh yang paling banyak diceritakan, baik sebagai pelaku kejadian maupun yang dikenai kejadian.

Saat menentukan siapa tokoh utama dalam novel RTDW ini, kita tidak akan menemukan namanya pada bab pertama. Namun, judul bab 2 secara tegas menjadikan nama tokoh utamanya sebagai judul bab "Aku Rehan". Setelah kita membaca secara keseluruhan, kita dapat mengetahui bahwa tokoh Rehan atau lebih sering disebut Ray 
adalah tokoh utama satu-satunya yang selalu diceritakan dengan runtut dari bab satu hingga bagian akhir. Dalam novel RTDW, tidak ada satu bagian pun yang tidak terkait dengan tokoh utamanya.

Berkaitan dengan tinjauan psikoloanalisis, di awal cerita dikisahkan bahwa tokoh Ray adalah contoh tokoh yang belum dapat mengendalikan dorongan $i d$ nya. Setiap ia mengalami kemalangan atau kesedihan akan nasibnya, ia senantiasa memberontak dan tidak jarang pula ia memprotes takdir Tuhan akan dirinya. Ia dikisahkan juga belum mampu mengambil tindakan yang tepat dalam setiap keputusan penting yang ia ambil. Contoh dorongan id yang muncul dan tidak dapat dikendalikan oleh ego dan superego-nya terlihat dalam kutipan berikut ini.

Berbeda dengan anak-anak panti lainnya yang tumbuh tertekan, Rehan tumbuh melawan. Kepintarannya menjelma menjadi sebuah perlawanan paling logis. Dia sering membantah perintah penjaga. Bertanya banyak hal. Menyudutkan. Berbantah-bantah. Penjaga panti yang tidak suka melihat anak-anak banyak bicara langsung membungkamnya dengan pecutan bilah rotan. Semakin banyak pecut rotan mendera tubuhnya, Rehan tumbuh semakin berbeda. (halaman 35)

Dari kutipan di atas jelas terlihat bahwa Rehan lebih dominan mengikuti dorongan $i d$ nya. Perbuatan-perbuatan negatif yang dia lakukan merupakan suatu bentuk yang merujuk pada pencapaian kepuasan dengan segera. Dia tidak lagi memperhatikan nilai-nilai sosial dan moral yang berlaku di masyarakat. Ego-nya lebih mendukung pemuasan id-nya dan super ego Ray tidak mampu menghadang dorongan $i d$-nya. Hal tersebut dapat kita lihat juga dalam kutipan berikut ini.

Perlawanan yang menemui tembok itu berubah menjadi "perang" gerilya. Celakanya, itu sekaligus mengajari Rehan hal-hal buruk. Mulailah secara otodidak dia mencuri makanan di dapur. Membawa tumpukan makanan ke kamar dengan seringai muka penuh kemenangan. Rehan mulai berani mangkir kerja, sengaja merusak barang-barang dan berbagai perangai buruk bentuk perlawanan lainnya. (halaman 35)

Kemarahan akan takdir jalan hidupnya seringkali diungkapkan dengan kalimat-kalimat protes pada Tuhan. Kutipan 
bentuk protesnya kepada Tuhan dapat dilihat di bawah ini.

Apakah kami memang tidak pernah memiliki kesempatan untuk memilih saat akan dilahirkan? (halaman 55)

Kutipan di atas adalah bentuk protes tokoh utama sekaligus menjadi pertanyaan pertama yang seringkali muncul dan bergejolak di hatinya. Pertanyaan yang sudah muncul saat Ray masih anak-anak, saat ia mempertanyakan mengapa ia harus tinggal $\mathrm{di}$ panti yang ia benci.

Apa semua ini adil? Di mana rasa keadilan Tuhan? Mengapa semuanya harus terjadi ketika janji baik itu persis tiba? Kenapa Tuhan sepertinya suka sekali merenggut kebahagiaan orang-orang yang selalu baik? (halaman 137)

Kutipan di atas adalah pertanyaanpertanyaan Ray saat mengamuk dengan hati terluka pada preman-preman yang melukai teman-temannya sesama penghuni rumah singgah. Anak-anak rumah singgah itu baginya lebih dari keluarga karena di sanalah ia tahu betapa menyenangkan memiliki saudara dan merasakan kebersamaan yang menenteramkan.

Kemarahan tokoh utama pada Tuhan juga muncul kembali pada saat ia teringat akan nasib teman-teman rumah singgahnya dan juga penyebab (kebakaran yang disengaja) ia menjadi anak panti. Kemarahannya pada Tuhan terlihat jelas dalam kutipan berikut ini.

Kalau hidup ini adil kenapa mereka dibiarkan oleh Tuhan? KENAPA?! (halaman 167)

Ada kutipan lain yang menunjukkan ungkapan kemarahan dan protes Ray pada Tuhan saat ia tepekur di kursi lorong rumah sakit tempat istrinya dirawat setelah pendarahan hebat yang mengakibatkan ia kehilangan bayi pertamanya. Kutipan saat tokoh utama novel TRDW memprotes takdir Tuhan juga terlihat dalam kutipan berikut ini. Apakah Kau tega sekali lagi merenggut kebahagiaan itu. Kebahagiaan istrinya? Setelah bertahun-tahun menjalani pahit-getir itu? Apakah Kau akan selalu mengambil kebahagiaan dari orangorang baik? (halaman 292)

Puncak kemarahan Ray sekaligus puncak konflik novel RTDW ini sangat terlihat dalam kutipan di bawah ini.

Apa maksud semua ini Tuhan? Kenapa Kau tega sekali? Kau renggut bayi kami tiga tahun silam. Dan sekarang Kau renggut istri dan bayiku sekaligus. Apakah Kau tertawa 
melihat kami tersungkur seperti ini? Tertawa puas? (halaman 313)

Dalam kutipan di atas terlihat id tokoh utama cerita ini lebih dominan menguasai batinnya. Ia merasa bahwa saat ia sudah mulai mengikuti dorongan ego dan superegonya dengan berumah tangga dan bekerja dengan baik, ia akan mendapat kebahagiaan. Takdirnya ternyata tidak sesuai dengan harapannya. Ia tetap merasakan ketidakadilan akan hidupnya serta kesedihan yang beruntun. Keputusasaan akan takdir hidup tokoh utama pun diungkapkan oleh pengarangnya dalam kutipan berikut ini.

... Ray yang kenyang dengan pahit getirnya kehidupan, tumbuh subur dengan bekas luka dan lebam kerasnya jalanan, besar dengan pecut bilah rotan maupun bilah kenyataan, akhirnya mendesah tertahan menatap rembulan, bertanya mengapa Tuhan tidak menjemputnya saja langsung. Mengapa dia harus mengalami semua sakit ini. Apakah langit tidak kunjung puas melemparkannya dalam kegetiran hidup? Apakah semua sesak pertanyaannya selama ini belum cukup? Enam tahun itu berlalu menyedihkan. (halaman 401)
Dalam novel RTDW, tampak pula saat id diikuti oleh ego tokoh utama novel ini. Terutama saat ia kembali berjaya dalam usahanya. Hal tersebut dapat terlihat dalam kutipan berikut ini.

Ray memutuskan untuk menjalaninya bagai air. Air bah yang menakutkan. Usia Ray 50 tahun, ketika dia berhasil mengambil alih secara paksa bisnis keuangan Mister Liem. Melalui serangkaian permainan keuangan canggih, memanfaatkan isu politik tingkat tinggi, desas-desus yang membuat panik, hingga rush besarbesaran di bank swasta itu. Saat mulut Mister Liem mulai kemasukan air yang mencapai lehernya, Ray menenggelamkannya. (halaman 393)

Ada beberapa peristiwa saat id tokoh utama muncul dan menjadi lebih dominan dan superego-nya muncul karena ia diingatkan oleh pembina rumah singgah, yaitu Bang Ape. Kalimat-kalimat yang membuat tokoh utama terinspirasi melawan dominasi $i d$-nya dan menyelaraskan dengan tuntutan superego terlihat dalam kutipan berikut ini.

Setidaknya kau punya aktivitas, Ray. Mengisi waktu luang dengan hal-hal positif. Siapa tahu kau akan lebih banyak tersenyum setelah pergi 
sekolah. Kami bosan melihat kau hanya melamun dan menyeringai. (halaman 89)

Kutipan di atas adalah saran yang diberikan Bang Ape agar Ray mau mendaftarkan diri ikut sekolah informal. Bang Ape memberinya motivasi untuk sekolah lagi karena ia melihat Ray adalah anak yang pendiam, lebih banyak menyendiri hanya sibuk memperhatikan. Ray hanya tersenyum kecil kalau ditegur, mengangguk pendek kalau ditanya, menggeleng pelan kalau diajak. Selain itu, anak-anak rumah singgah lainnya rata-rata juga bersekolah sesuai dengan saran Bang Ape.

Di samping menyarankan untuk sekolah, Bang Ape pun sering sekali mengingatkan anak-anak rumah singgah untuk melupakan masa lalu mereka yang buruk. Ia mengingatkan bahwa mereka memiliki kekuatan untuk mengubah nasib dan menentukan masa depan mereka sendiri. Kutipan perkataan Bang Ray pada anak-anak rumah singgah yang seringkali diucapkan dan terdengar amat bertenaga, selalu memberikan motivasi, menusuk serta membangkitkan semangat adalah berikut ini.

Kalian mungkin memiliki masa lalu yang buruk, tapi kalian memiliki kepal tangan untuk merubahnya. yang meminta Ray untuk menyadari bahwa
Kepal tangan yang akan menentukan sendiri nasib kalian hari ini, kepal tangan yang akan melukis sendiri masa depan kalian. (halaman 96)

Selain itu, Bang Ray pun mengingatkan anak-anak rumah singgah bahwa mereka semua adalah saudara yang membuat tokoh utama novel RTDW ini merasakan janji kehidupan yang lebih baik. Ia merasakan rumah singgah beserta isinya memberikan sepotong kehidupan baru yang indah baginya. Ia merasakan bahwa anakanak rumah singgah menjadi lebih dari sebuah keluarga baginya. Ray bahkan berjanji bahkan bersumpah dalam hatinya bahwa ia akan membela mereka dari siapa saja yang berbuat tidak menyenangkan. Kutipan kalimat Bang Ape yang membuat $i d$, ego, dan superego tokoh utama muncul secara beriringan adalah berikut ini.

Kalian akan tetap menjadi saudara di mana pun berada, kalian sungguh akan tetap menjadi saudara. Tidak ada yang pergi dari hati. Tidak ada yang hilang dari sebuah kenangan. Kalian sungguh akan tetap menjadi saudara. (halaman 97)

Ada pula kalimat-kalimat Bang Ape 
tidak semua persoalan hanya bisa diselesaikan dengan menyalahkan dan lantas membalas. Kalimat yang ditulis dua kali pada halaman berbeda dan sangat berarti menghidupkan ego dan superego tokoh utama novel ini adalah berikut ini.

Tahukah kau, kita bisa menukar banyak hal menyakitkan yang dilakukan orang lain dengan sesuatu yang lebih hakiki, lebih abadi. Rasa sakit yang timbul karena perbuatan aniaya dan menyakitkan dari orang lain itu sementara, Ray. Pemahaman dan penerimaan tulus dari kejadian yang menyakitkan itulah yang abadi. (halaman 110 dan halaman 212)

Kalimat yang sama dituliskan dua kali dalam halaman berbeda menegaskan bahwa inilah amanat yang ingin disampaikan pengarang dalam karyanya. Rasa sakit atau penderitaan yang dirasakan akibat perbuatan jahat orang lain hanyalah sementara karena yang abadi adalah penerimaan yang tulus akan rasa sakit itu sehingga kita dapat mengambil hikmah dari semua rasa sakit yang kita rasakan. Apabila kita dapat menerimanya dengan tulus maka rasa sakit itu lama-lama akan hilang dan akan dijadikan bahan pembelajaran di masa yang akan datang.
Tokoh lain yang dikisahkan sebagai "orang dengan wajah menyenangkan" juga menggali pergolakan batin tokoh utama agar $i d$, ego, dan superegonya muncul secara beriringan. Penulis novel RTDW ini melalui tokoh "orang dengan wajah menyenangkan" menitipkan pesan-pesan positif tentang kehidupan untuk pembacanya. Tentang nilai keadilan versi Tuhan, tentang perbandingan baik-buruk, kaya-miskin, cantik-jelek, serta sebab dan akibat suatu kejadian. Kutipankutipan kalimat yang membangunkan superego sekaligus menjawab pertanyaanpertanyaan si tokoh utama adalah berikut ini.

Ray, kehidupan ini selalu adil. Keadilan langit mengambil berbagai bentuk. Meski tidak semua bentuk itu kita kenali, tapi apakah dengan tidak mengenalinya kita bisa beraniberaninya bilang Tuhan tidak adil? Hidup tidak adil? Ah kau ini telanjur sulit bagimu, karena kau keras kepala. (halaman 172)

Ray, semua itu hanya perbandingan. Otak manusia sejak lama terlatih menyimpan banyak perbandingan berdasar versi mereka sendiri, menerjemahkan nilai seratus itu bagus, nilai lima puluh itu jelek. Wajah seperti ini cantik, wajah seperti itu jelak. Hidup seperti itu 
kaya, hidup seperti itu miskin. Otak manusia yang keterlaluan pintarnya mengumpulkan semua kejadiankejadian itu dalam sebuah buku besar yang disebut buku perbandingan. Buku itu lantas diserahterimakan kepada generasi penerusnya, selalu diperbaharui sesuai kebutuhan zaman, yang sayangnya dalam banyak hal, lama-lama perbandingan itu amat menyedihkan. Mempunyai banyak harta benda itu baik, miskin papa itu jelek. Benar-benar ukuran yang tidak hakiki. Bagaimana mungkin posisinya tetap lebih baik kalau harta benda itu didapatkan dengan caracara yang tidak baik? Bagaimana pula tetap jelek kalau kemiskinan itu memberikan kehormatan hidup? (halaman 415-416)

Angkat kepalamu Ray! Lihat gadis kecil di ayunan. Nama anak itu Rinai. Ia lahir berdarah-darah sehari kemudian setelah kecelakaan tersebut dari rahim ibunya yang telah menjadi bangkai. Kelahiran yang menyedihkan. Dokter berkutat mengambil bayi prematur itu dari mayat ibunya. Lihatlah Ray! Kau pikir kaulah yang paling berhak mengutuk Tuhan? Menyalahkan seluruh dunia? Kau pikir kaulah yang memiliki takdir paling menyakitkan? Kau sungguh keliru, Ray. Sungguh keliru.... Gadis kecil itu lebih menyakitkan, dan kaulah penyebabnya. (halaman 420)

Di akhir cerita penulis RTDW ini menjelaskan bentuk superego tokoh utama yang diceritakan oleh "orang dengan wajah menyenangkan" dapat kita lihat dalam kutipan berikut ini.

Setiap kali kau memandangnya, kau selalu berterima kasih kepada Tuhan. Setiap kali kau menyimaknya, kau selalu merasa kuasa Tuhan menjejak setiap sudut bumi di mana cahaya rembulan menyentuhnya. Kau memiliki cara berinteraksi yang luar biasa dengan kuasa langit, Ray.... Kau memang mengutuk, membantah, berprasangka buruk kepada Tuhan, tetapi kau jujur. Kau tidak pernah berdusta saat menghadap rembulan. Tidak pernah munafik. Apa adanya. (halaman 424)

Kau selalu merasa andaikata semua kehidupan ini menyakitkan, maka di luar sana pasti masih ada sepotong bagian yang menyenangkan. Kemudian kau akan membenak, pasti 
ada sesuatu yang jauh lebih indah dari menatap rembulan di langit. Kau tidak tahu apa itu, karena ilmumu terbatas, pengetahuanmu terbatas. Kau hanya yakin, bila tidak di kehidupan ini, suatu saat nanti pasti akan ada yang lebih mempesona dibandingkan menatap sepotong rembulan yang sedang bersinar indah. (halaman 424)

Dari kutipan di atas terlihat bahwa tokoh utama walaupun di awal cerita lebih dikuasai oleh id dan ego-nya, namun superego-nya tetap muncul terutama saat ia memandang rembulan. Ray, tokoh utama cerita dalam novel RTDW ini masih memiliki hati nurani walaupun ilmunya terbatas. Ia masih bisa bersangka baik pada Tuhan bahwa pasti ada sesuatu yang lebih indah dibandingkan menatap rembulan.

\section{SIMPULAN}

Novel Rembulan Tenggelam Di Wajahmu, ditinjau dari aspek kejiwaannya, tokoh Ray atau Rehan mempunyai proses perkembangan kejiwaan yang cukup rumit. Kesedihan yang dialaminya dari mulai dari masa kecilnya di panti, kematian istri dan anaknya, hingga perkembangan usahanya menimbulkan lima pertanyaan besar dalam batinnya.
Pada bagian awal, id Ray muncul secara dominan dan terlihat tidak mampu diimbangi oleh ego dan superego-nya. Untung saja ada beberapa saat di mana $i d$ Ray muncul dan menjadi dominan, yaitu saat ia mendapatkan motivasi dari Bang Ape. Namun ada saat di mana Ray tidak dapat menerima kenyataan bahwa anak dan istrinya meninggal. Ia merasa Tuhan tidak bersikap adil padanya dan suka merenggut kebahagiaan dari orang-orang baik.

Di balik semua bentuk protesnya pada Tuhan, superego tokoh utama RTDW ini masih muncul terutama saat melihat rembulan. Oleh karena itu Ray diberi kesempatan lima hari sebelum kematiannya untuk mengendalikan dominasi id-nya sehingga akhirnya $i d$, ego, dan superego-nya berjalan beriringan. 


\section{DAFTAR PUSTAKA}

Ba'dulu, Abdul Muis dan Herman. 2005. Morfosintaksis. Jakarta: Rineka Cipta Ahmadi, Abu. 1992. Psikologi Umum. Jakarta: Rineka Cipta.

Bertens, K. 2006. Psikoanalisis Sigmund Freud. Jakarta: PT Gramedia.

Endraswara, Suwardi. 2003. Metodologi Penelitian Sastra: Epistimologi, Model, Teori, dan Aplikasi. Yogyakarta: Pustaka Widyatama.

Freud, Sigmund.1984. Memperkenalkan Psikoanalisa. Jakarta: Gramedia.

Freud, Sigmund. 1983. Sekelumit Sejarah Psikoanalisa. Jakarta: Gramedia.

Liye, Tere. 20011. Rembulan Tenggelam Di Wajahmu. Jakarta: Republika.

Nurgiyantoro, Burhan. 2007. Teori Pengkajian Fiksi. Yogyakarta: Gajah Mada University Press.

Pradopo, Rachmat Djoko. 1994. Beberapa Teori Sastra Metode Kritik dan Penerapannya. Yogyakarta: Jendela.

Sangidu. 2016. "Kondisi Kejiwaan Para Tokoh dalam "Kānat Hiyal-Adh'āf" Karya Nawal El Sa'dawi” dalam Atavisme Volume 19 No.2 Tahun 2016.

Yusuf, Syamsu dan Juntika Nurihsan. 2007.

Teori Kepribadian. Bandung: Rosda Karya.

Wellek, Rene dan Austin Warren. 1995. Teori Kesusastraan. Jakarta: Gramedia. 